\title{
Mechanical Strength and
} Stability of Lithium Aluminate

\author{
J. L. Brimhall
}

June 1992

Prepared for the U.S. Department of Energy under Contract DE-AC06-76RLO 1830

Pacific Northwest Laboratory

Operated for the U.S. Department of Energy

by Battelle Memorial Institute

\section{Battelle}




\title{
DISCLAIMER
}

This report was prepared as an account of work sponsored by an agency of the United States Covernment. Neither the United States Government nor any agency thereof, nor Battelle Memorial institute, nor any of their employees, makes any warranty, expressed or implied, or assumes any legal liability ur responsibility for the accuracy, completeness, or usefulness of any information, apparatus, product, or process disclosed, or represents that its use would not infringe privately owned rights. Reference herein to any specific commercial product, process, or service by trade name, trademark, manufacturer, or otherwise does not necessarily constitute or imply its endorsement, recommendation, or favoring by the United States Government or any agency thereof, or Battelle Memorial institute. The views and opinions of authors expressed herein do not necessarily state or reflect those of the United States Government or any agency thereof.

\author{
PACIFIC NORTHWEST LABORATORY \\ operated by \\ BATTELLE MEMORIAL INSTITUTE \\ for the \\ UNITED STATES DEPARTMENT OF ENERGY \\ under Contract DE-AC06-76RLO 1830
}

Printed in the United States of America

\begin{abstract}
Available to DOE and DOE contractors from the
Onfice of Scientific and Technical Information, P.O. Box 62, Oak Ridge, TN 37831;

prices available from (615) 576-8401. FTS 626-8401.
\end{abstract}

Available to the public from i'se National Technical Information Service,

U.S. Department of Commerce, 5285 Port Royal Rd., Springfield, Vi் 22161. 
MECHANICAL STRENGTH AND STABILITY OF LITHIUM ALUMINATE

J. L. Brimhall

June 1992

Prepared for

the U.S. Department of Energy

under Contract DE-AC06-76RLO 1830

Pacific Northwest Laboratory

Richland, Washington 99352 
Pacific Northwest Laboratory (PNL) investigated the strength and resistance to thermal shock of lithium aluminate annular pellets. The room temperature, axial compressive fracture strength of pellets made at Westinghouse Advanced Energy Systems (WAES) varied from 80 to $133 \mathrm{ksi}$. The strength at $430^{\circ} \mathrm{C}\left(806^{\circ} \mathrm{F}\right)$ was 30 to $40 \%$ lower. The strength at $900^{\circ} \mathrm{C}\left(1652^{\circ} \mathrm{F}\right)$ showed a wide variation with one measurement near $90 \mathrm{ksi}$. These strength values are consistent with other data and predictions made in the literature when the grain size and porosity of the microstructure are taken into account. In diametral compression tests, the fracture strengths were much lower due to the existence of tensile stresses in some pellet regions from this type of loading. However, the fracture stresses were still generally higher than those reported in the literature; this fracture resistance probably reflects the better quality of the pellets tested in this study. Measurements on pellets made at PNL indicated lower strengths compared to the WAES material. This strength difference could be accounted for by different processing technologies: material made at PNL was cold-pressed and sintered with high porosity whereas the WAES material was isostatically hot-pressed with high density. Thermal shocking of the material by ramping to $900^{\circ} \mathrm{C}$ in two minutes did not have an observable effect on the microstructure or the strength of any of the pellets. 


\section{ACKNOWLEDGMENT}

The assistance of Ryan Pestes of the Department of Energy in developing the software for computing the tensile stresses in the pellets is greatly appreciated. 
CONTENTS

SUMMARY $\ldots \ldots \ldots \ldots \ldots \ldots \ldots \ldots \ldots \ldots \ldots$

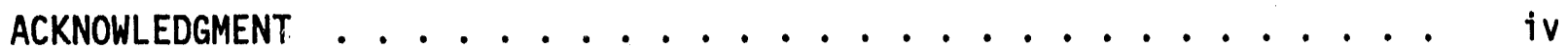

1.0 INTRODUCTION $\ldots \ldots \ldots \ldots \ldots \ldots . \ldots \ldots \ldots$

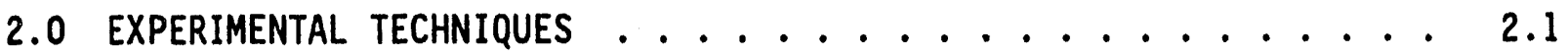

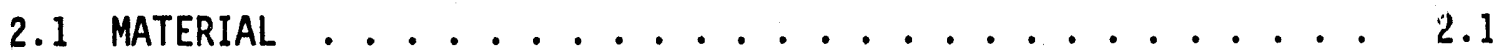

2.2 THERMAL SHOCK TESTING $\ldots \ldots \ldots \ldots . \ldots \ldots$

2.3 MECHANICAL PROPERTY TESTING . . . . . . . . . 2.2

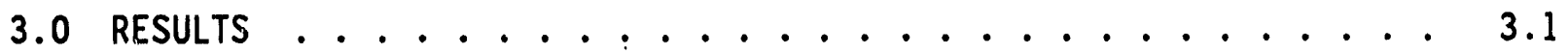

3.1 THERMAL SHOCK TESTS .............. 3.1

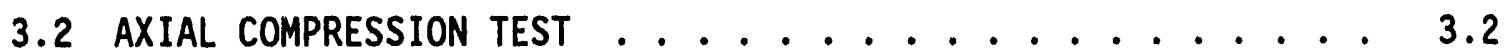

3.3 DIAMETRAL COMPRESSION TESTS $\ldots \ldots \ldots \ldots . \ldots . \ldots$

3.4 TESTS ON PNL PROCESSED MATERIAL $\ldots \ldots \ldots \ldots$

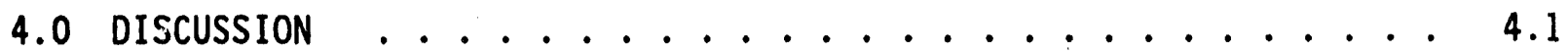

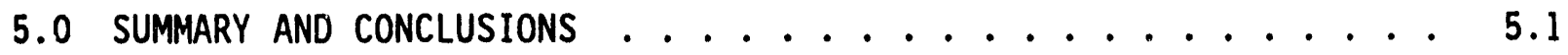

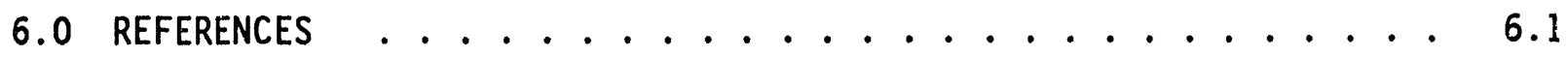




\section{FIGURES}

1 Typical Heating Rate Curve for LiAlO, Pellets in the Thermal Shock Tests ................ 3.1

2 Microstructure of As-Received $\mathrm{LiAlO}_{2}$, Specimen 44-1 . . . . . . 3.3

3 Microstructure of Thermally Shocked $\mathrm{LiAlO}_{2}$, Specimen $25-1$. . . . 3.3

4 Diametral Loading of the Pellet Showing Regions Where High Tensile Stresses Exist ............... 3.7

5 Fracture Surface of Pellet After Diametral Compression Test, a) Ambient Temperature b) $900^{\circ} \mathrm{C}$. . . . . . . . . 3.9

6 Fracture Surface of PNL Pellet Material . . . . . . . . . 3.10

7 Temperature Dependence of Axial Compressive Strength . . . . 4.2

8 Temperature Dependence of Tensile Fracture Stress. . . . . . . 4.3

\section{TABLES}

1 Axial Compressive Strength - Ambient Temperature . . . . . . 3.4

2 Axial Compressive Strength - Elevated Temperature . . . . . 3.5

3 Diametral Compressive Strength - Room Temperature . . . . . . 3.6

4 Diametral Compressive Strength - Elevated Temperature . . . . 3.8

5 Axial Compressive Strength - PNL Material .......... 3.10

6 Diametral Compressive Strength - PNL Material . . . . . . 3.10 


\subsection{INTRODUCTION}

Lithium aluminate is $\mathrm{planned}$ for use as a target in the light-water-new production reactor (LWR-NP). This material will be in the form of annular pellets located in the reactor core. To evaluate the target material's performance in the reactor core, it is important to understand the mechanical strength of lithium aluminate pellets under normal reactor operating conditions. In addition, thermal shock stresses from transients associated with a loss-of-coolant-accident (LOCA) or other abnormal reactor conditions could adversely affect the mechanical properties of lithium aluminate.

Pacific Northwest Laboratory (PNL) ${ }^{(a)}$ has conducted mechanical testing to determine the strength and resistance of lithium pellets to thermal shock. Mechanical testing was performed on pellets for several temperature and baseline, non-irradiated material conditions. This report describes the procedures, results, and conclusions of the mechanical testing. Additional information on material test objectives, test plans, and test procedures are described in previous studies (Brimha11 1990a, 1990b, 1990c).

(a) Pacific Northwest Laboratory is operated for the U.S. Department of Energy under Contract DE-ACO6-76RLO 1830. 


\subsection{EXPERIMENTAL TECHNIQUES}

The following sections describe briefly the materials and experimental conditions that were used in performing the tests.

\subsection{MATERIAL}

Most of the specimen material was obtained from WAES and was in the form of annular, pellets, 0.29-in. outside diameter and varying in length from 0.8 to $1.8 \mathrm{in}$. This material was obtained from that used to fabricate the Advanced Test Reactor capsule and Loop Target Rods (Kuhns 1988). The wall thickness was nominally $0.040 \mathrm{in}$. In addition, several pellets made at PNL were also tested. All of the pellets had a numerical code that is traceable to the processing history.

The pellets were cut into sections approximately 0.5-in. long for the compression testing. End sections were ground so that the end faces were parallel to \pm 0.0005 in. As-received material was tested for thermal shock and cut into sections for compression testing after the thermal shock treatment. Measurements of the length, diameter, and wall thickness were taken with a digital, calibrated micrometer on all specimens before testing. Three separate measurements were taken of each dimension. Visual observations with a low power microscope $(7 X)$ were made on the pellets, and any pellet showing noticeable degradation was not used.

\subsection{THERMAL SHOCK TESTING}

Pellets were thermally shocked by rapid heating to $900^{\circ} \mathrm{C}$ within a quartz tube, radiant heating furnace. During heating, argon gas continually flowed around the pellet material. A calibrated thermocouple was placed inside the pellet to ensure that the measured temperature rise corresponded to the inner surface of the pellet. The outside surface would experience a higher heating rate to make the overall test conservative. Preliminary testing of one pellet established the power level to be used to obtain a heating rate near the desired $5.5^{\circ} \mathrm{C} / \mathrm{sec}\left(10^{\circ} \mathrm{F} / \mathrm{sec}\right)$ (Sathyanatayana et al. 1989). This rate was used 
for all the subsequent testing. The furnace was turned off when temperature was reached, and the specimen was allowed to cool in the flowing argon.

After the thermal shock tests, the samples were visually inspected for signs of damage. One specimen was polished for ceramographic analysis. The remaining specimens were cut and prepared for mechanical property testing.

\subsection{MECHANICAL PROPERTY TESTING}

The pellets were tested in axial compression in which the load was applied along the axis of the pellet and in diametral compression in which the load was applied across the diameter of the pellet. The load was applied so that failure occurred in a 1 - to 3 -minute period. This resulted in a crosshead displacement rate of $0.01 \mathrm{in.} / \mathrm{min}$. Heavy paper was placed between the platens and the specimen for the ambient temperature tests, and iron shim stock was used for the elevated temperature tests.

For elevated temperature tests, a muffle furnace was placed around the push rods and platens. A SiC tube was placed around the sample to catch the debris after failure. A hole in the siC shroud allowed a thermocouple to be $\mathrm{placed}$ within several $\mathrm{mm}$ of the pellet. The reading from this thermocouple was used as a measure of the specimen temperature. Most elevated temperature testing was done at $430^{\circ} \mathrm{C}\left(806^{\circ} \mathrm{F}\right)$, but several samples were al so tested at $900^{\circ} \mathrm{C}\left(1652^{\circ} \mathrm{F}\right)$. 


\subsection{RESULTS}

\subsection{IHERMAL SHOCK TESTS}

The thermal shock tests were designed to simulate a heating rate expected during a LOCA. A typical heating rate curve for the thermal shock tests is shown in Figure 1. The heating rate is not 1 inear but is more rapid initially and decreases at higher temperature. Although the same power setting was used on each test, the actual heating rates varied from $4.5^{\circ} \mathrm{C} / \mathrm{sec}$ to $5.8^{\circ} \mathrm{C} / \mathrm{sec}$ for the tested pellets. This heating rate is based on the time required to heat from $300^{\circ} \mathrm{C}$ to $900^{\circ} \mathrm{C}$.

The pellets did not show any signs of visible degradation as a result of this thermal shock treatment. There was a general discoloration, but this appeared to only be a surface phenomenon. There was no evidence of cracking when viewed under a low power $(7 X)$ optical microscope. Higher magnification

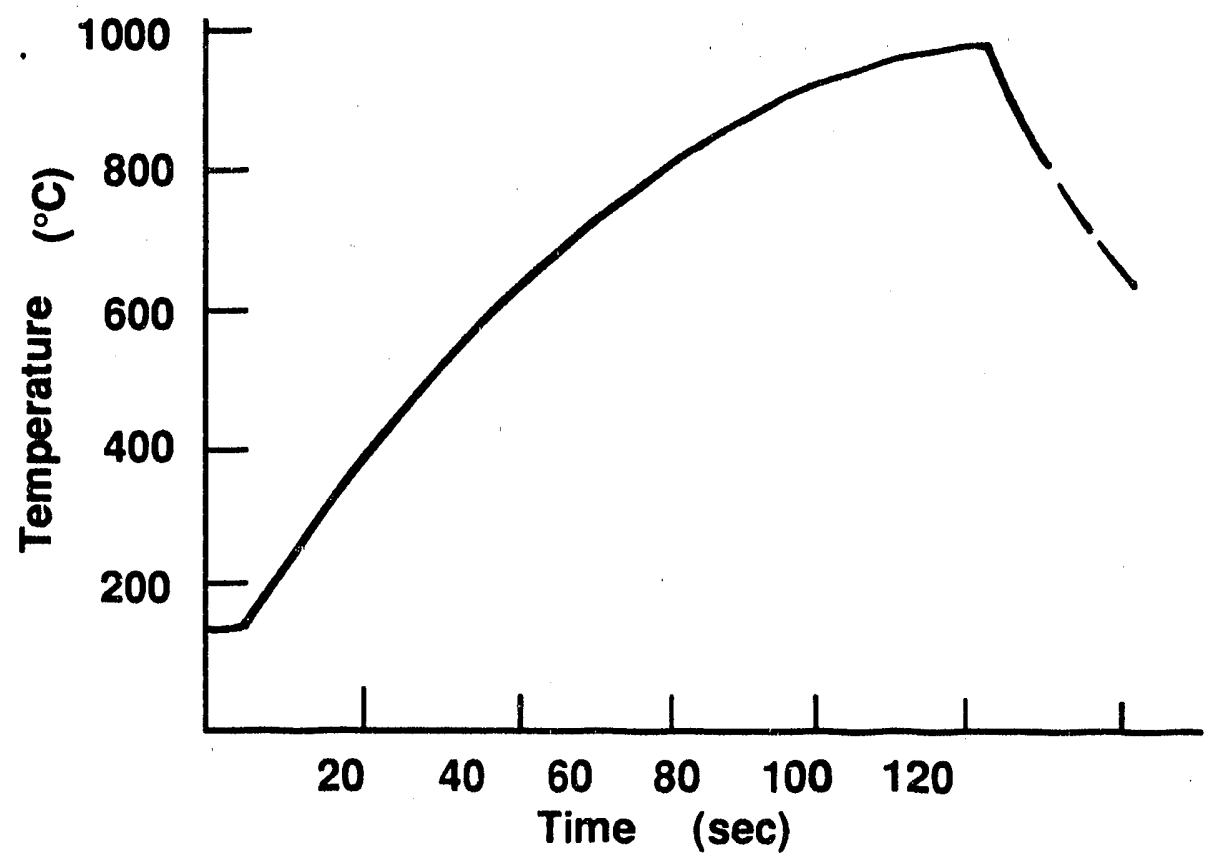

FIGURE 1. Typical Heating Rate Curve for $\mathrm{LiAlO}_{2}$ Pellets in the Thermal Shock Tests 
of polished cross-sections did not reveal any difference in the microstructure between an as-received specimen and a thermally shocked specimen, as shown by the comparison of Figures 2 and 3 . There was no noticeable difference in the porosity of the microstructure.

\subsection{AXIAL COMPRESSION TESTS}

The results of the axial compression tests at ambient temperature are presented in Table 1 . From 10 tests on as-received material, the strength values varied from a low of $76 \mathrm{ksi}$ to a maximum of $124 \mathrm{ksi}$. The magnitudes of these strength values are quite reasonable even though there is a relatively wide range in the scatter of the data. There appears to be no relation of the scatter to differences in the pellet numbers which were originally ascribed by WAES. The longer pellets obtained from WAES were cut into three test pellets, e.g., pellet 14-1 in Table 1. The maximum scatter in the data was actually observed when comparing the three values from a pellet with the same original WAES number as shown by the first three sample numbers in Table 1.

Tests on the thermally shocked material, labeled with the TS designation in Table 1, produced approximately the same range of strength values. The values range from a low of $80 \mathrm{ksi}$ to a maximum of $133 \mathrm{ksi}$. As was observed in the as-received (not thermally shocked) material, the maximum scatter occurred within the three test samples cut from a pellet with the same number. The results show conclusively that the thermal shock used in these tests does not weaken the pellet.

Results from tests at elevated temperatures are given in Table 2. Tests at $430^{\circ} \mathrm{C}$ show strength values ranging from $37 \mathrm{ksi}$ to $71 \mathrm{ksi}$. This is still a rather large scatter but the values are consistently below the values obtained at ambient temperature. The average value at $430^{\circ} \mathrm{C}$ is a 1 ittle more than half the value at ambient temperature.

Only three tests were performed at $900^{\circ} \mathrm{C}$ and the results are somewhat unexpected. The value of $25 \mathrm{ksi}$ is low but consistent with a continuing drop in strength with increase in temperature. The other two values ( $>90 \mathrm{ksi}$ ) are very high and comparable to those obtained in ambient temperature tests. 


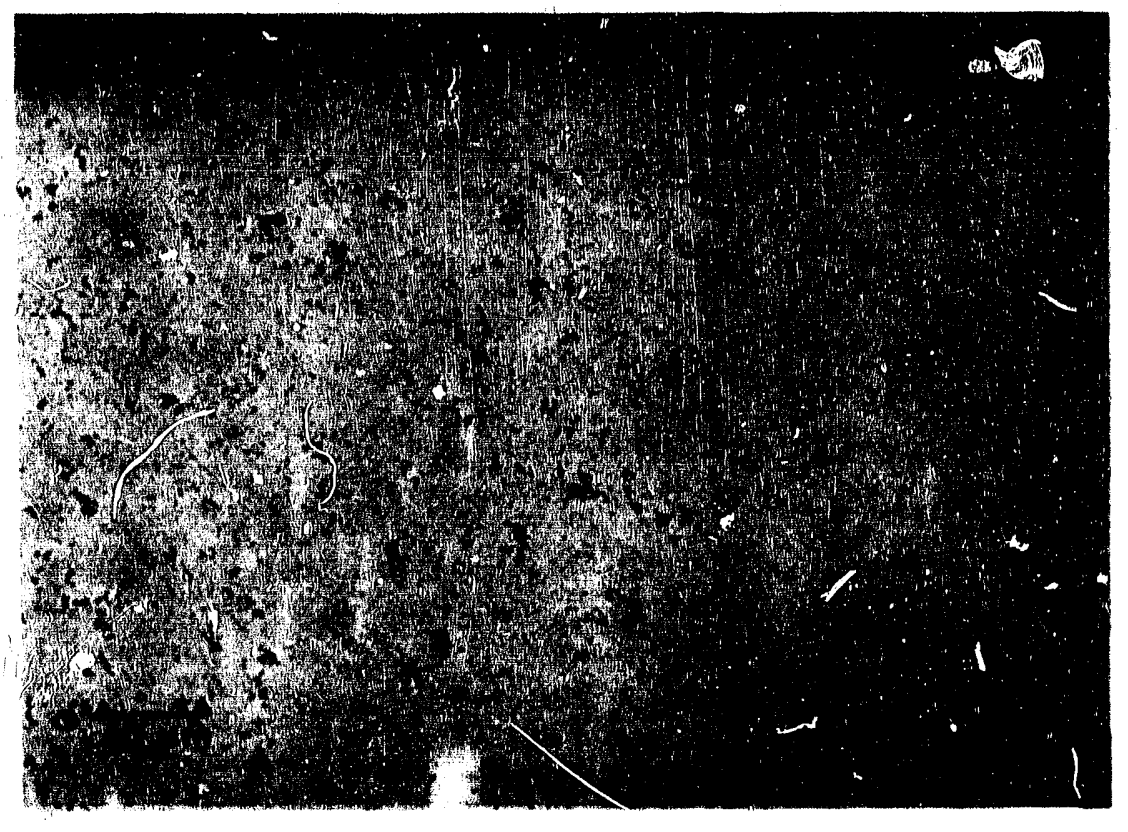

EIGURE_2. Microstructure of As-Received $\mathrm{LiAlO}_{2}$, Specimen 44-1

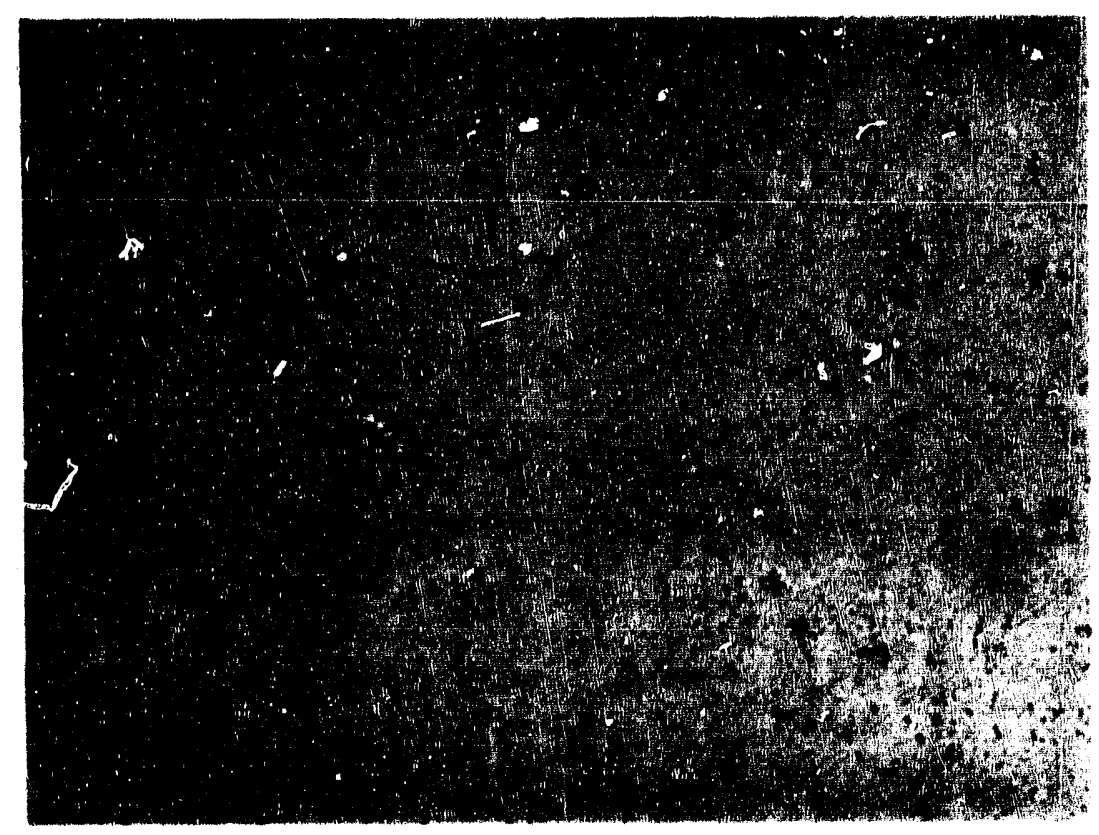

EIGURE 3. Microstructure of Thermally Shocked LiAlO 
TABLE 1. Axial Compressive Strength - Ambient Temperature

\begin{tabular}{|c|c|c|c|c|c|}
\hline $\begin{array}{l}\text { Sample } \\
\text { Number }\end{array}$ & $\begin{array}{l}\text { Outside } \\
\text { Diameter } \\
\text {-(in.) }\end{array}$ & $\begin{array}{l}\text { Inside } \\
\text { Diameter } \\
\text { (in.) }\end{array}$ & $\begin{array}{l}\text { Length } \\
\text { Lin. }\end{array}$ & $\begin{array}{l}\text { Load } \\
(1 \mathrm{~b})\end{array}$ & $\begin{array}{l}\text { Fracture } \\
\text { Strength } \\
\text { ísi) } \\
\end{array}$ \\
\hline $14-1-A C-1$ & 0.290 & 0.211 & 0.565 & 2,550 & 82,030 \\
\hline i4-1-AC-2 & 0.290 & 0.211 & 0.564 & 3,800 & 123,570 \\
\hline $14-1-A C-3$ & 0.290 & 0.211 & 0.565 & 2,325 & 75,600 \\
\hline $34-3-A C-1$ & 0.290 & 0.210 & 0.560 & 2,625 & 84,450 \\
\hline $34-3-A C-2$ & 0.290 & 0.212 & 0.565 & 3,275 & 105,360 \\
\hline $34-3-A C-3$ & 0.290 & 0.214 & 0.565 & 3,250 & 108,030 \\
\hline $24-1-A C-1$ & 0.290 & 0.212 & 0.535 & 3,200 & 104,060 \\
\hline $24-1-A C-2$ & 0.290 & 0.213 & 0.535 & 3,300 & 108,500 \\
\hline $29-4-A C-1$ & 0.290 & 0.212 & 0.565 & 2,376 & 78,100 \\
\hline $29-4-A C-2$ & 0.290 & 0.212 & 0.564 & 3,600 & 118,350 \\
\hline 17-1-AC-TS-1 & 0.290 & 0.212 & 0.535 & 3,900 & 125,470 \\
\hline $17-1-A C-T S-2$ & 0.290 & 0.213 & 0.533 & 3,875 & 128,800 \\
\hline $17-1-A C-T S-3$ & 0.290 & 0.214 & 0.534 & 3,575 & 118,840 \\
\hline $28-4-A C-T S-1$ & 0.290 & 0.214 & 0.565 & 4,000 & 132,960 \\
\hline 28-4-AC-TS-2 & 0.290 & 0.212 & 0.564 & 2,450 & 79,670 \\
\hline $28-4-A C-T S-3$ & 0.290 & 0.212 & 0.565 & 3,925 & 127,630 \\
\hline
\end{tabular}


IABLE 2. Axial Compressive Strength - Elevated Temperature

\begin{tabular}{|c|c|c|c|c|c|c|}
\hline $\begin{array}{l}\text { Sample } \\
\text { Number }\end{array}$ & $\begin{array}{c}\text { Temperature } \\
\left({ }^{\circ} \mathrm{C}\right)\end{array}$ & $\begin{array}{l}\text { Outside } \\
\text { Diameter } \\
\text { (in.) }\end{array}$ & $\begin{array}{c}\text { Inside } \\
\text { Diameter } \\
\text { (in.) }\end{array}$ & $\begin{array}{l}\text { Length } \\
\text { (in.) }\end{array}$ & $\begin{array}{l}\text { Load } \\
(1 b) \\
\end{array}$ & $\begin{array}{l}\text { Fracture } \\
\text { Strength } \\
\text { (psi) }\end{array}$ \\
\hline $21-3-H T-A C-1$ & 430 & 0.290 & 0.211 & 0.535 & 2,188 & $71,1=0$ \\
\hline $21-3-H T-A C-2$ & 430 & 1.290 & 0.212 & 0.535 & 2,200 & 71,540 \\
\hline $21-3-H T-A C-3$ & 430 & 0.290 & 0.212 & 0.535 & 1,300 & 42,740 \\
\hline $34-6-H T-A C-1$ & 430 & 0.290 & 0.213 & 0.563 & 1,420 & 47,200 \\
\hline $34-6-H T-A C-2$ & 430 & 0.290 & 0.212 & 0.563 & 1,140 & 37,070 \\
\hline $34-6-H T-A C-3$ & 430 & 0.290 & 0.213 & 0.565 & 1,200 & 39,450 \\
\hline $20-4-H T-A C-1$ & 900 & 0.290 & 0.211 & 0.563 & 780 & 25,090 \\
\hline $20-4-H T-A C-2$ & 900 & 0.290 & 0.211 & 0.563 & $2,92 b$ & 94,100 \\
\hline $20-4-H T-A C-3$ & 900 & 0.290 & 0.212 & 0.565 & 2,825 & 91,860 \\
\hline
\end{tabular}

There was no apparent plastic deformation of the pellets at ambient temperature or at $430^{\circ} \mathrm{C}$. Failure was instantaneous and resulted in complete puiverization of the material. Failure at $900^{\circ} \mathrm{C}$ produced larger chunks of material, and it is possitle that some plastic deformation occurred. This may account for the apparent increase in strength at this temperature.

\subsection{DIAMETRAL COMPRESSION TESTS}

Results of the diametral compression tests at room temperature are shown in Table 3. The load at fracture has been converted to load per unit length and ranges from 120 to $180 \mathrm{lbs} /$ in. Figure 4 shows the regions where high tensile stresses would exist. The stress distribution is quite complex for this type of loading and is computed using the following relationship (Durelli and Lin 1986):

$$
\left(\sigma_{q}\right)_{i}=-M_{0} P / \pi R_{0} t+P / \pi R_{0} t\left(-M_{2} \cos 2 \theta+M_{4} \cos 4 \theta-M_{6} \cos 6 \theta+\ldots\right)
$$




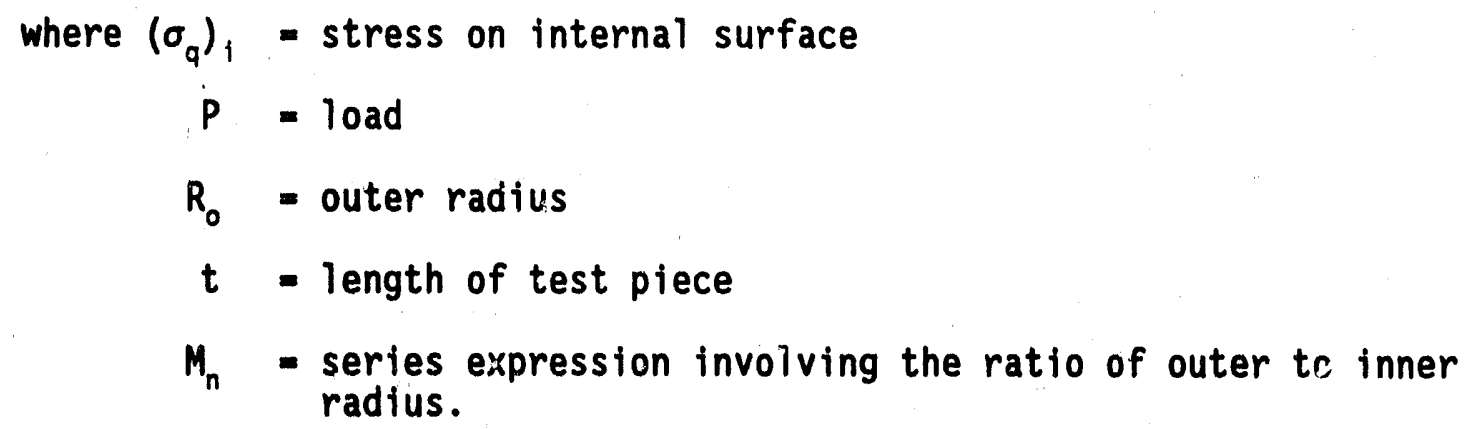

IABLE 3. Diametral Compressive Strength - Room Temperature

\begin{tabular}{ccccccc}
$\begin{array}{c}\text { Sample } \\
\text { Number }\end{array}$ & $\begin{array}{c}\text { Outside } \\
\text { Diameter } \\
\text { (in.) }\end{array}$ & $\begin{array}{c}\text { Inside } \\
\text { Diameter } \\
\text { (in.) }\end{array}$ & $\begin{array}{c}\text { Lengih } \\
\text { (in.) }\end{array}$ & $\begin{array}{c}\text { Load/ } \\
\text { Length } \\
\text { (lb/in.) }\end{array}$ & $\begin{array}{c}\text { Fracture } \\
\text { Stress } \\
\text { (psi) }\end{array}$ \\
\hline $62-2-D C-1$ & 0.290 & 0.210 & 0.490 & 126 & 18,930 \\
$62-2-D C-2$ & & 0.290 & 0.210 & 0.533 & 182 & 27,500 \\
$45-2-D C-1$ & 0.290 & 0.209 & 0.512 & 179 & 27,552 \\
$45-2-D C-2$ & 0.290 & 0.211 & 0.603 & 181 & 29,368 \\
$45-2-D C-3$ & 0.290 & 0.210 & 0.573 & 163 & 25,821 \\
$008-2-D C-1$ & 0.290 & 0.210 & 0.581 & 139 & 21,925 \\
$008-2-D C-2$ & 0.289 & 0.209 & 0.489 & 156 & 19,615 \\
$008-6-D C-1$ & 0.290 & 0.209 & 0.493 & 121 & 18,295 \\
$008-6-D C-2$ & 0.289 & 0.210 & 0.503 & 154 & 24,937 \\
$33-1-D C-T S-1$ & 0.289 & 0.209 & 0.512 & 159 & 25,094 \\
$33-1-D C-T S-2$ & 0.289 & 0.210 & 0.584 & 163 & 26,238 \\
$33-1-D C-T S-3$ & 0.289 & 0.210 & 0.547 & 162 & 26,275 \\
$16-4-D C-T S-1$ & 0.290 & 0.208 & 0.565 & 157 & 23,403 \\
$16-4-D C-T S-2$ & 0.290 & 0.208 & 0.563 & 130 & 22,327
\end{tabular}




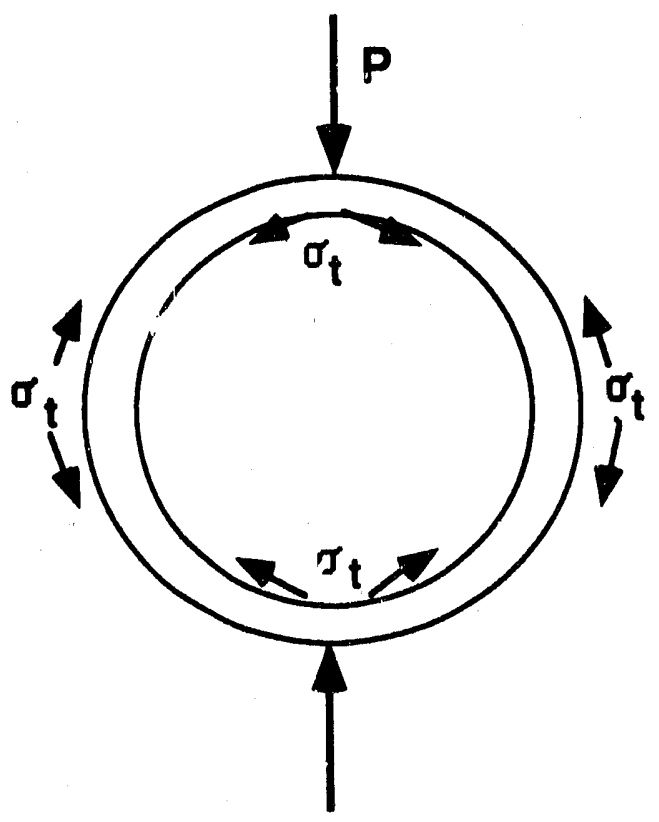

FIGURE 4. Diametral Loading of the Pellet Showing Regions Where High Tensile Stresses Exist

A similar expression can be used to calculate the stresses on the inner surface of the tube (Durelli and Lin 1986).

Solutions to Equation 1 show that the maximum tensile stresses occur at the top and bottom of the pellet and these are the calculated values listed in Table 3. The relative scatter in the data is about the same as that observed in the axial compression tests. The stress values at fracture are low because ceramics are notably very weak in tension.

There was no significant difference in the tensile fracture stresses for the thermally shocked material compared to the as-received material. This is consistent with the results of the axial compression test where no differences were seen. The scatter appeared to be somewhat less for the thermally shocked material compared to the as-received material.

The failure stress at elevated temperatures for the diametral compression test is given in Table 4. The values at $430^{\circ} \mathrm{C}$ are only about 25 to $30 \%$ of the values observed at room temperature. The relative decrease in strength with temperature is greater than that observed for axial compression tests. 
IABLE 4. Diametral Compressive Strength - Elevated Temperature

\begin{tabular}{|c|c|c|c|c|c|c|}
\hline $\begin{array}{l}\text { Sample } \\
\text { Number }\end{array}$ & $\begin{array}{l}\text { Temperature } \\
(\cdot \mathrm{C})\end{array}$ & $\begin{array}{l}\text { Outside } \\
\text { Diameter } \\
\text { (in.) } \\
\end{array}$ & $\begin{array}{c}\text { Inside } \\
\text { Diameter } \\
\text { (in.) }\end{array}$ & $\begin{array}{l}\text { Length } \\
\text { (in.) }\end{array}$ & $\begin{array}{l}\text { Load/ } \\
\text { Length } \\
\text { (lb/in.) }\end{array}$ & $\begin{array}{c}\text { Fracture } \\
\text { Stress } \\
\text { (psi) } \\
\end{array}$ \\
\hline $006-5-H T-D C-1$ & 400 & 0.290 & 0.212 & 0.557 & 45 & 7,847 \\
\hline $006-5-H T-D C-2$ & 400 & 0.290 & 0.213 & 0.531 & 39 & 6,775 \\
\hline $006-5-H T-D C-3$ & 430 & 0.290 & 0.213 & 0.528 & 44 & 7,467 \\
\hline $25-3-H T-D C-1$ & 430 & 0.290 & 0.212 & 0.511 & 46 & 7,673 \\
\hline $24-3-H T-D C-2$ & 430 & 0.290 & 0.212 & 0.490 & 50 & 8,742 \\
\hline $24-3-H T-D C-3$ & 430 & 0.290 & 0.212 & 0.488 & 50 & 8,377 \\
\hline $49-1-H T-D C-1$ & 430 & 0.290 & 0.212 & 0.609 & 25 & 4,450 \\
\hline $49-1-H T-D C-2$ & 600 & 0.290 & 0.212 & 0.530 & 44 & 7,384 \\
\hline $49-1-H i-D C-3$ & 900 & 0.290 & 0.212 & 0.524 & 79 & 14,530 \\
\hline
\end{tabular}

However, the one test at $900^{\circ} \mathrm{C}$ showed a higher fracture stress than that at $430^{\circ} \mathrm{C}$ but not as high as observed at room temperature. This agrees with some of the axial compression tests that showed higher compression strengths at $900^{\circ} \mathrm{C}$ compared to $430^{\circ} \mathrm{C}$.

Failure during the diametral compression tests did not pulverize the sample, primarily because the loads were much smaller than those of the axial compression tests. The samples fragmented into relatively large pieces. An example of the fracture surface after a diametral compression test at both ambient temperature and at $900^{\circ} \mathrm{C}$ is shown in Figure 5. The fracture surface after $900^{\circ} \mathrm{C}$ deformation was not as angular or faceted as the ambient deformation. The features were more rounded, which may indicate some plastic deformation at the higher temperature. The surfaces showed some areas of intergranular fracture from which it was estimated that the grain size was on the order of 2-3 microns. 

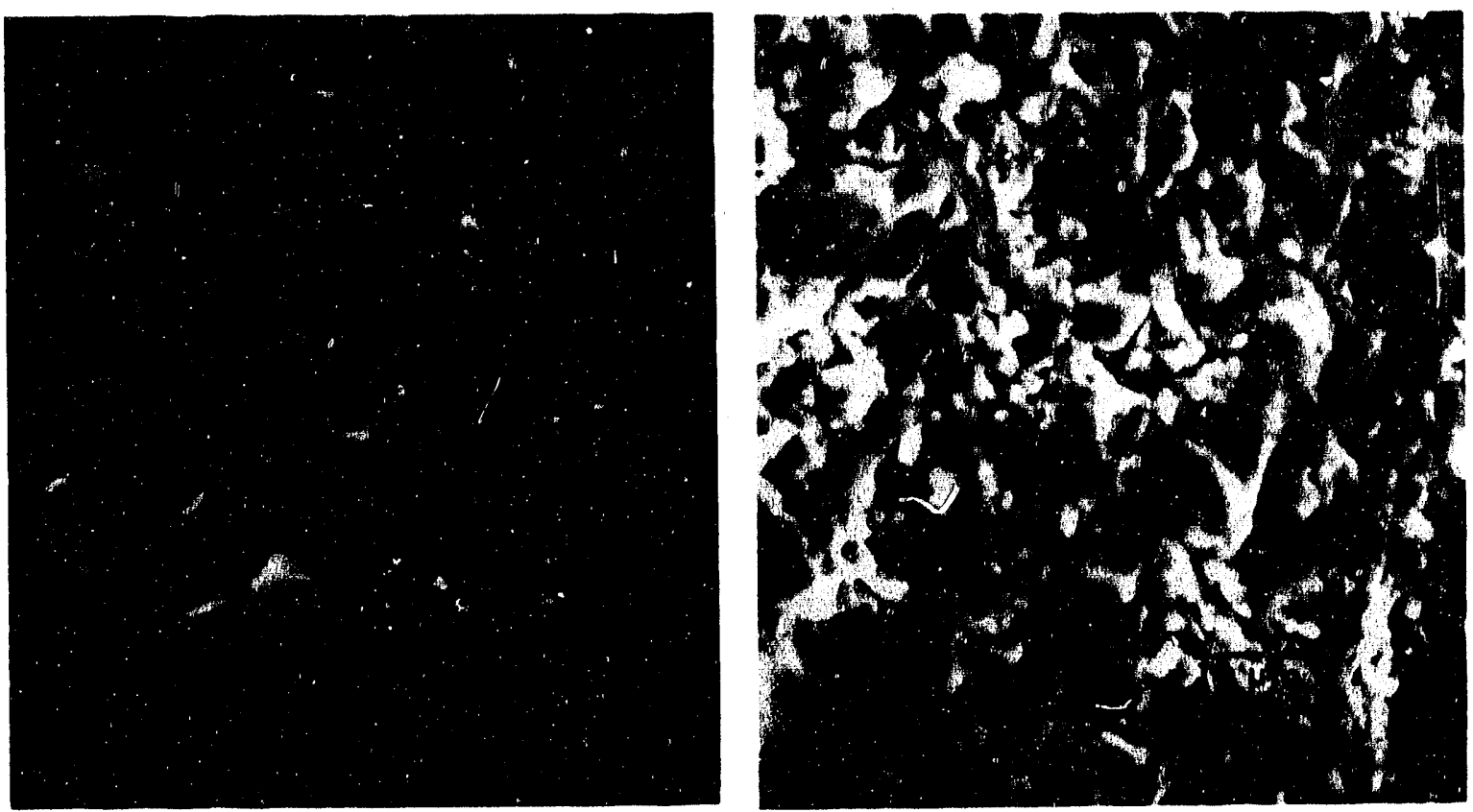

FIGURE 5. Fracture Surface of Pellet After Diametral Compression Test, a) Ambient Temperature b) $900^{\circ} \mathrm{C}$

\subsection{IESTS ON PNL PROCESSED MATERIAL}

Several compression tests were performed on pellets that were made at PNL. The results of the axial and diametral compression tests at room temperature are shown in Tables 5 and 6 , respectively. The axial compressive strength values are only about one-half the values obtained for the WAES pellet material. The diametral values in terms of load per unit length are also less than the values observed for the WAES material but proportionately greater than observed for the axial tests. Only three tests of each type were run, but there was little scatter in the results. The PNL pellets, Figure 6, appeared to show greater porosity than the WAES material, although quantitative measurements were not made. The grain size was difficult to measure but did not appear to differ greatly from the WAES material. 
TABLE 5. Axial Compressive Stength - PNL Material

\begin{tabular}{|c|c|c|c|c|c|}
\hline $\begin{array}{l}\text { Sample } \\
\text { Number }\end{array}$ & $\begin{array}{l}\text { Outside } \\
\text { Diameter } \\
\text { (in.) }\end{array}$ & $\begin{array}{l}\text { Inside } \\
\text { Diameter } \\
\text { (in.) }\end{array}$ & $\begin{array}{l}\text { Length } \\
\text { (in.) }\end{array}$ & $\begin{array}{l}\text { Load } \\
\text { (lb) }\end{array}$ & $\begin{array}{l}\text { Fracture } \\
\text { Strength } \\
\text { (psi) }\end{array}$ \\
\hline PNL - 2-AC-1 & 0.301 & 0.225 & 0.409 & 1,380 & 45,670 \\
\hline PNL-2-AC-2 & 0.301 & 0.227 & 0.408 & 1,310 & 42,210 \\
\hline PNL - 2-AC-3 & 0.302 & 0.221 & 0.410 & 1,310 & 38,430 \\
\hline
\end{tabular}

IABLE 6. Diametral Compressive Strength - PNL Material

$\begin{array}{ccccccc}\begin{array}{c}\text { Sample } \\ \text { Number }\end{array} & \begin{array}{l}\text { Outside } \\ \text { Diameter } \\ \text { (in.) }\end{array} & \begin{array}{l}\text { Inside } \\ \text { Diameter } \\ \text { (in.) }\end{array} & \begin{array}{l}\text { Length } \\ \text { (in.) }\end{array} & \begin{array}{l}\text { Load } \\ \text { (1b) }\end{array} & \begin{array}{r}\text { Load/ } \\ \text { Length } \\ \text { PNL-2-DC-1 }\end{array} \\ & 0.300 & 0.221 & 0.410 & 36.8 & 89.8 \\ \text { PNL-2-DC-2 } & 0.301 & 0.219 & 0.412 & 41.0 & 99.5 \\ \text { PNL-2-DC-3 } & 0.300 & 0.225 & 0.419 & 43.5 & 103.8\end{array}$

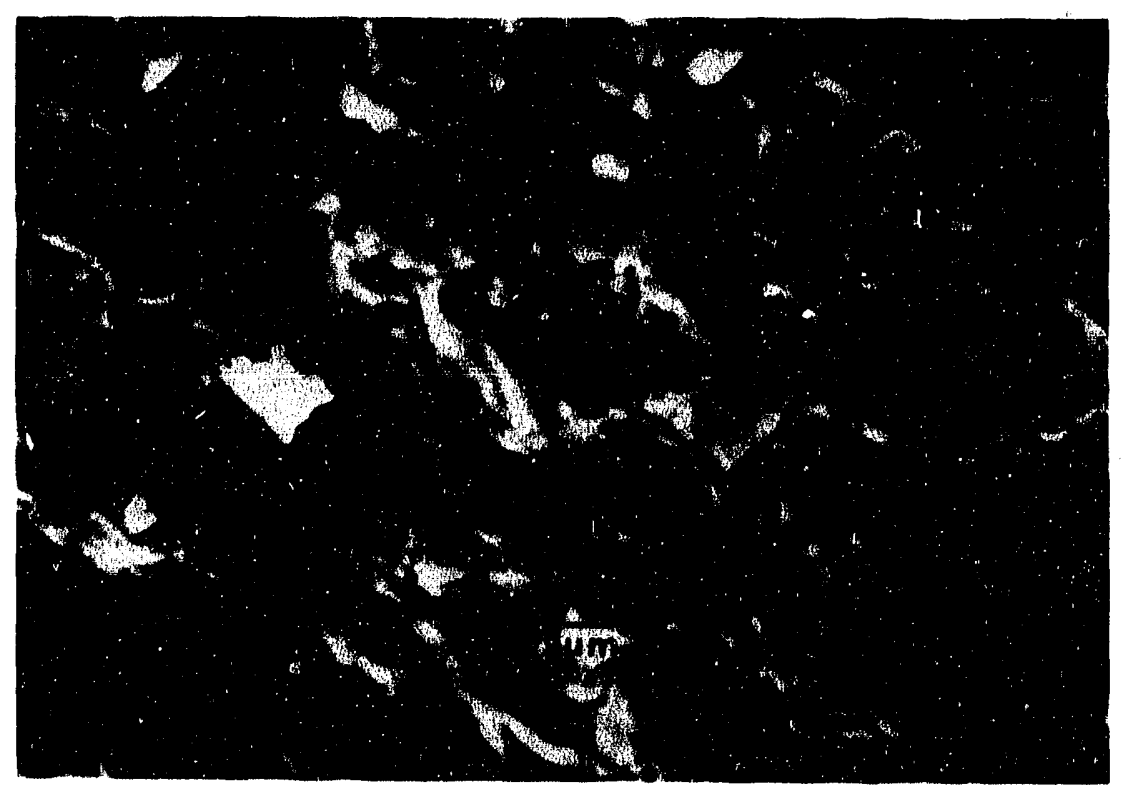

FIGURE 6. Fracture Surface of PNL Pellet Material Tested at Ambient Temperature 


\subsection{DISCUSSION}

The results of the axial compression tests correlate reasonably well with previous work (Rasneur 1985; Billone and Grayhack 1988) on 1ithium aluminate when the grain size and material density are taken into account. Rasneur (1985) has developed an empirical equation to relate the strength of the lithium aluminate to grain size, porosity and temperature; the equation is in the form:

$$
\sigma_{c}=\left(1000 / d^{1 / 2}\right)(\exp -10 p)(\ln 2200 / T)
$$

$$
\text { where } \begin{aligned}
\sigma_{c} & =\text { compressive fracture strength in } \mathrm{MPa} \\
d & =\text { grain size in microns } \\
p & =\text { fractional porosity } \\
T & =\text { temperature in } K .
\end{aligned}
$$

Calculated curves of strength versus temperature for several grain sizes and a porosity of 0.05 (equivalent to WAES pellets) are shown in Figure 7 . The range of stress values obtained for the WAES material is shown on the same plot for temperatures of $20^{\circ}$ and $430^{\circ} \mathrm{C}$, respectively. The measured values generally fall within the calculated range for grain size between 2 and 4 microns. Grain size, as estimated from SEM micrographs, was within this range. The grain size dependence of the strength is fairly strong and may account for some of the scatter in the data, if the processing parameters varied from batch to batch.

It is more likely that the scatter in the data is related to variation in the structural defects of the pellets. The fracture behavior of brittle ceramics is very sensitive to defects in the material, such as cracks or inclusions. While the surface appeared to be free of defects, internal defects could be present which would reduce the fracture strength. Two of the data points at $900^{\circ} \mathrm{C}$ are unexpectedly high, whereas one data point is consistent with the empirical curve. The specific data from which Equation 2 was derived were not provided by Rasneur (1985), so it is not known if there are other data that actually extend to a test temperature of $900^{\circ} \mathrm{C}$. 


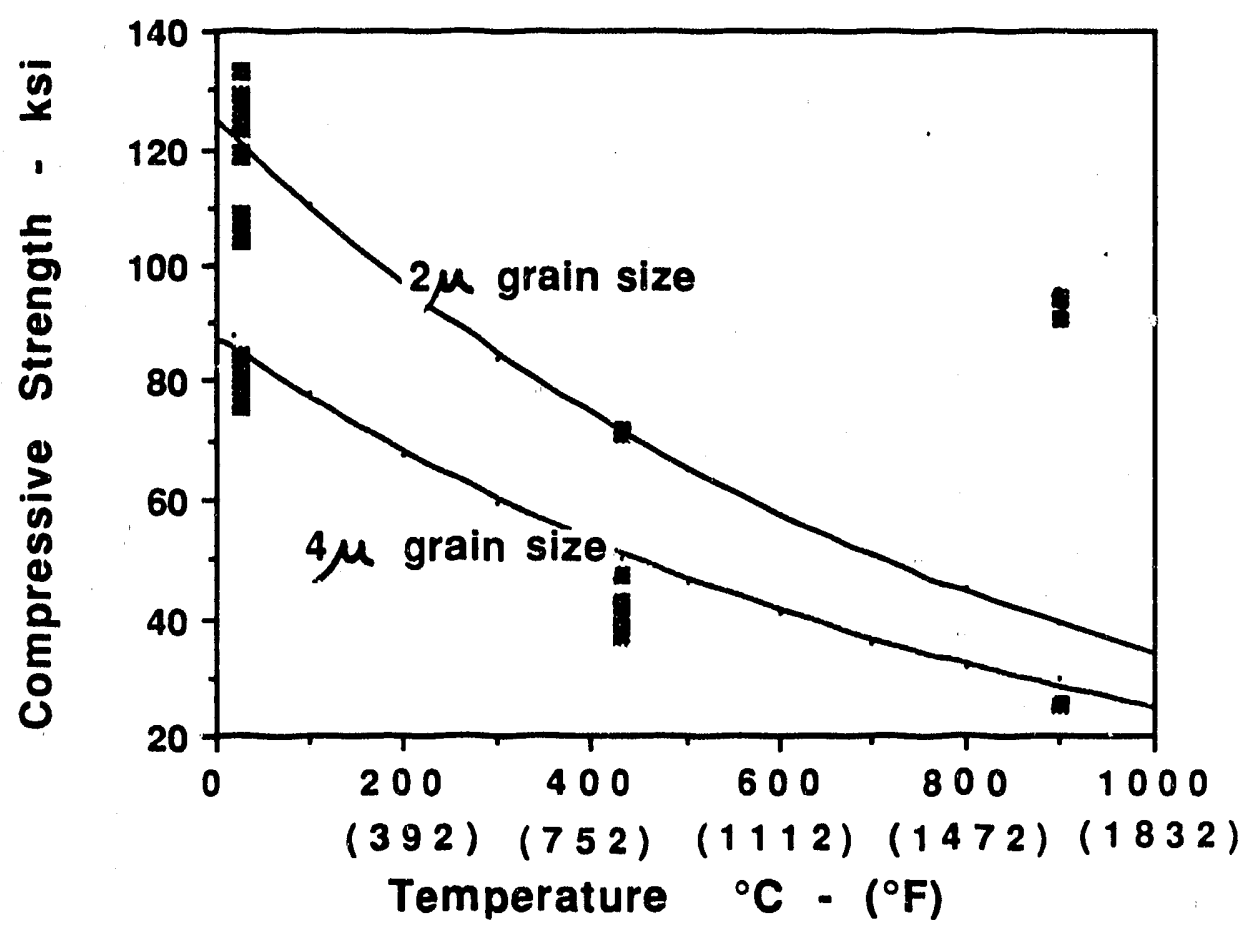

FIGURE 7. Temperature Dependence of Axial Compressive Strength. Smooth curves represent Equation 2 for grain sizes of 2 and 4 microns and $5 \%$ porosity. Data points are from current tests on WAES pellets.

An explanation for the high fracture values at $900^{\circ} \mathrm{C}$ is not immediately obvious but is probably related to a change in the process controlling the fracture. At low temperature, the defects in the structure control the fracture stress, and the material fails at stresses much lower than the true yield stress. At temperatures where plastic flow can occur, defects no longer control the fracture and the fracture stress would be higher than the yield stress. A temperature of $900^{\circ} \mathrm{C}$ may be the lower limit at which plastic flow begins, which could explain why some tests show high strength and others do not. The pellets fragmented into larger pieces at $900^{\circ} \mathrm{C}$; otherwise, there was no visible evidence of plastic flow. For conservatism, the lower fracture values at $900^{\circ} \mathrm{C}$ would have to be assumed. A more complete series of tests covering a wide temperature range between $400-1000^{\circ} \mathrm{C}$ would be required to justify use of the higher strength data at $900^{\circ} \mathrm{C}$.

The data for the diametral tests, which provide some measure of failure stress under tensile loading, can also be compared to an empirical equation. 
An empirical equation similar to Equation 2 has also been reported (Billone and Grayhack 1988) and is of the form:

$$
\sigma_{t}=\left(62 / d^{1 / 2}\right)(\exp -4.3 p)(\ln 2200 / T)
$$

where $\sigma_{t}$ is the fracture stress in tension, and the other parameters are the same as in Equation 2. The calculated curves for grain sizes of 2 and 4 microns are shown in Figure 8 along with other data in the literature and data from the present study.

The empirical equation shows a continual decrease in strength with temperature. However, the data from Billone and Grayhack (1988), which is for bend tests of material with grain size of 1 micron, shows a continual increase

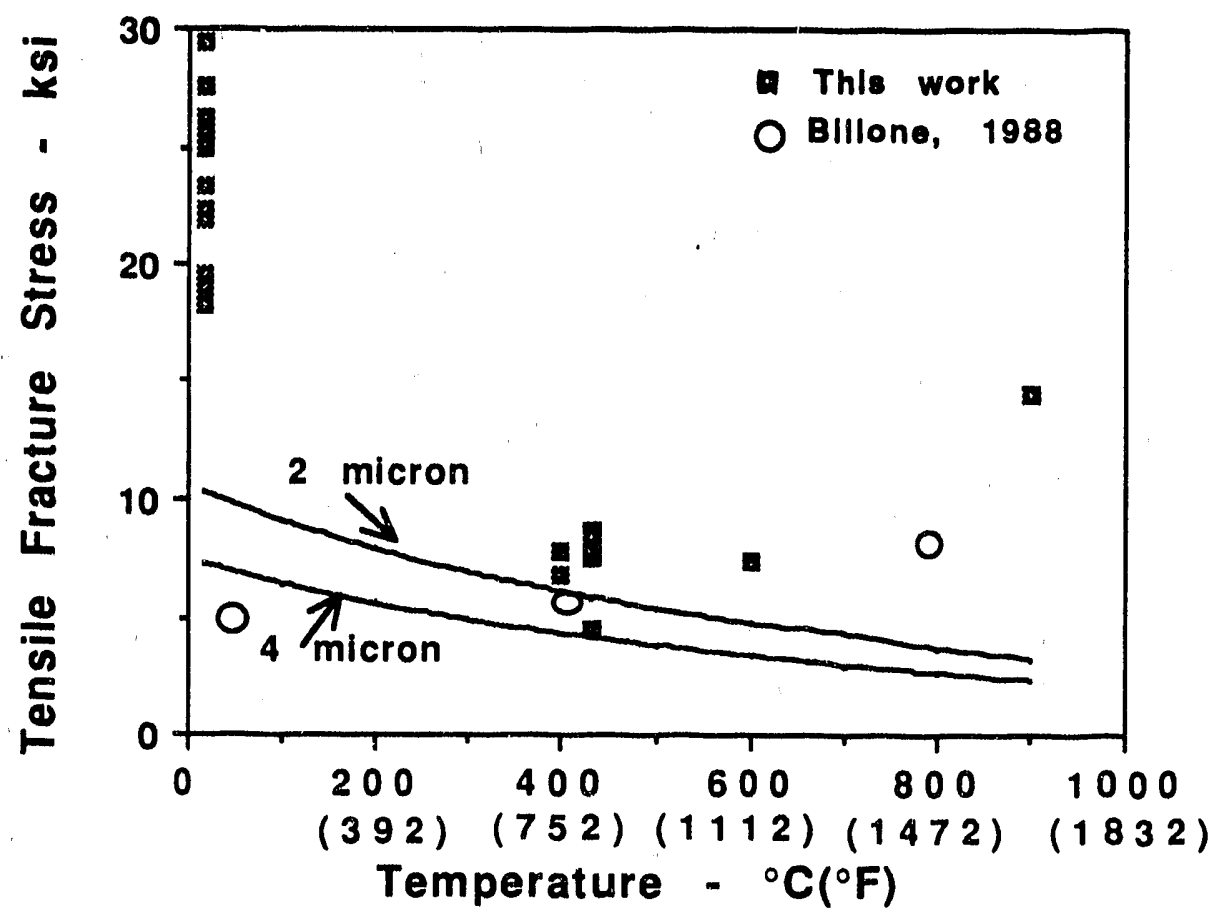

FIGURE 8. Temperature Dependence of the Tensile Fracture Stress. Curves are from Equation (2) for grain sizes indicated. Data points are from the tests on WAES pellets and from Billone and Grayhauk (1988) for a grain size of 1 micron. 
of strength with temperature. Tho tensile fracture stress from large-grain size material first increased and then decreased with temperature.

The data from this study show decreasing fracture strength with temperature up to $430^{\circ} \mathrm{C}$ but then a possible increasing of strength at higher temperatures. There was only a single data point at the high temperature, so the effect may :ot be as strong as indicated. However, it is consistent with the axial compression data which also showed some high strength values at $900^{\circ} \mathrm{C}$.

The tensile fracture stress of the WAES pellets is considerably higher than that shown for bend tests. Some of this discrepancy is due to the different type of test, but primarily the higher density of the WAES pellets accounts for the greater tensile stress at fracture. All previous data has been taken from material with densities ranging from 71 to $79 \%$ density compared to $95 \%$ for the pellets tested here.

The load-to-fracture per unit length of pellet may be more useful data than the actual tensile stresses in the pellets because interactions between the outer tube and the pellets can produce a diametral-type load across the pellet. Axial compressive data are relevant to axial column loading on pellets.

The lower strength of the PNL pellet material is most likely due to difference in pellet processing. The WAES pellets were prepared using hot isostatic pressing, whereas the PNL pellets were cold-pressed and then sintered at a high temperature. Hot isostatic pressing should produce a more homogeneous material. The increase in porosity of the PNL material could also lead to a decrease in strength. However, according to Equation 2, an increase in porosity from 5 to $10 \%$ would decrease the strength about $10 \%$ if other parameters are equal. Other effects such as grain size and anisotropy of the microstructure must also be playing a role. 


\subsection{SUMMARY AND CONCLUSIONS}

The following conclusions are based on the mechanical properties testing of lithium aluminate.

- Thermal shock treatment of $300^{\circ} \mathrm{C} / \mathrm{min}$ does not degrade the 1 ithium aluminate pellets.

- Compressive strengths in the range of 80 to $130 \mathrm{ksi}$ have been measured at ambient temperature.

- The strength decreases by a factor of two at $430^{\circ} \mathrm{C}$ compared to room temperature. There is some indication that the pellets retain considerable strength at $900^{\circ} \mathrm{C}$; however, additional tests are needed to confirin this observation.

- The pellets can withstand loads of approximately $150 \mathrm{lbs} / \mathrm{in}$. when stressed in a diametrai direction. Maximum tensile stresses in the pellet at time of fracture are on the order of $30 \mathrm{ksi}$.

- The diametral strength is much reduced at $430^{\circ} \mathrm{C}$ compared to room temperature. However, there was indicatior that the strength was higher at $900^{\circ} \mathrm{C}$ than at $430^{\circ} \mathrm{C}$. This trend is similar to that shown in the axial compressive strength tests.

- The strength of pellets made at PNL was about one-half that of the pellets made at WAES. The difference is probably due to the processing used in making the pellets. 


\subsection{REFERENCES}

Billone, M. C., and W. T. Grayhack. 1988. "Summary of Mechanical Properties Data and Correlations for $\mathrm{Li}_{2} \mathrm{O}, \mathrm{Li}_{4} \mathrm{SiO}_{4}, \mathrm{LiAlO}_{2}$ and $\mathrm{Be}, " \mathrm{ANL} / \mathrm{FPP} / \mathrm{TM} 218$.

Brimhal1, J. L. 1990a. Test Requirements for the Evaluation of Mechanical Stability of Lithium Aluminate. Tritium Target Development Program, Pacific Northwest Laboratory, Richland, Washington.

Brimha17, J. L. 1990b. Test Plan for the Evaluation of Mechanical Strength and Stability of Lithium Aluminate. Tritium Target Development Program, Pacific Northwest Laboratory, Richl and, Washington.

Brimha11, J. L. 1990c. Test Procedure for Evaluation of Mechanical Strength and Stability of Lithium Aluminate. TTDP-4-003, Tritium Target Development Program, Pacific Northwest Laboratory, Richland, Washington.

Durelli, A. J., and Y. H. Lin. 1986. "Stresses and Displacements on the Boundaries of Circular Rings Diametrically Loaded," J. Applied Mechanics. $53: 213$.

Kuhns, G. W. 1988. Lithium Aluminate Powder and Pellet Fabrication Optimization. WSR-88-151, Westinghouse Advanced Energy Systems, Pittsburgh, Pennsylvania.

Rasneur, B. 1985. "Tritium Breeding Material: $\gamma$ LiAl $_{2} 0$," Fusion Technology, 8:1909-1914.

Sathyanarayana, K., D. M. Ogden, and S. R. Wagoner. 1989. WNP-1 Tritium Target LOCA Analysis. WHC-SP-0513, Westinghouse Hanford Company, Richland, Washington. 


\section{DISTRIBUTION}

No. of

Copies

OFFSITE

12 DOE/ Office of Scientific and Technical Information

2 U.S. Department of Energy Headquarters

Office of Light Water Reactor Office of New Production Reactor 1000 Independence Ave. SW Washington, DC 20585

ATTN: M. J. Clausen

W. F. Kelly

\section{ONSITE}

DOE Richland Field Office

E. A. Erichsen, A4-26
No. of

Copies

24 Pacific Northwest Laboratory

W. J. Apley, P8-34.

G. H. Beeman, P8- $\$ 4$ (3)

J. L. Brimhall (5)

R. G. Clemmer, P7-14

M. D. Freshiey, $P B-34$

E. R. Gilbert, P8-34 (5)

M. A. McKinnon, $P B-10$

J. P. Pilger, PS-34

Publishing Coordination

Technical Report Files (5) 

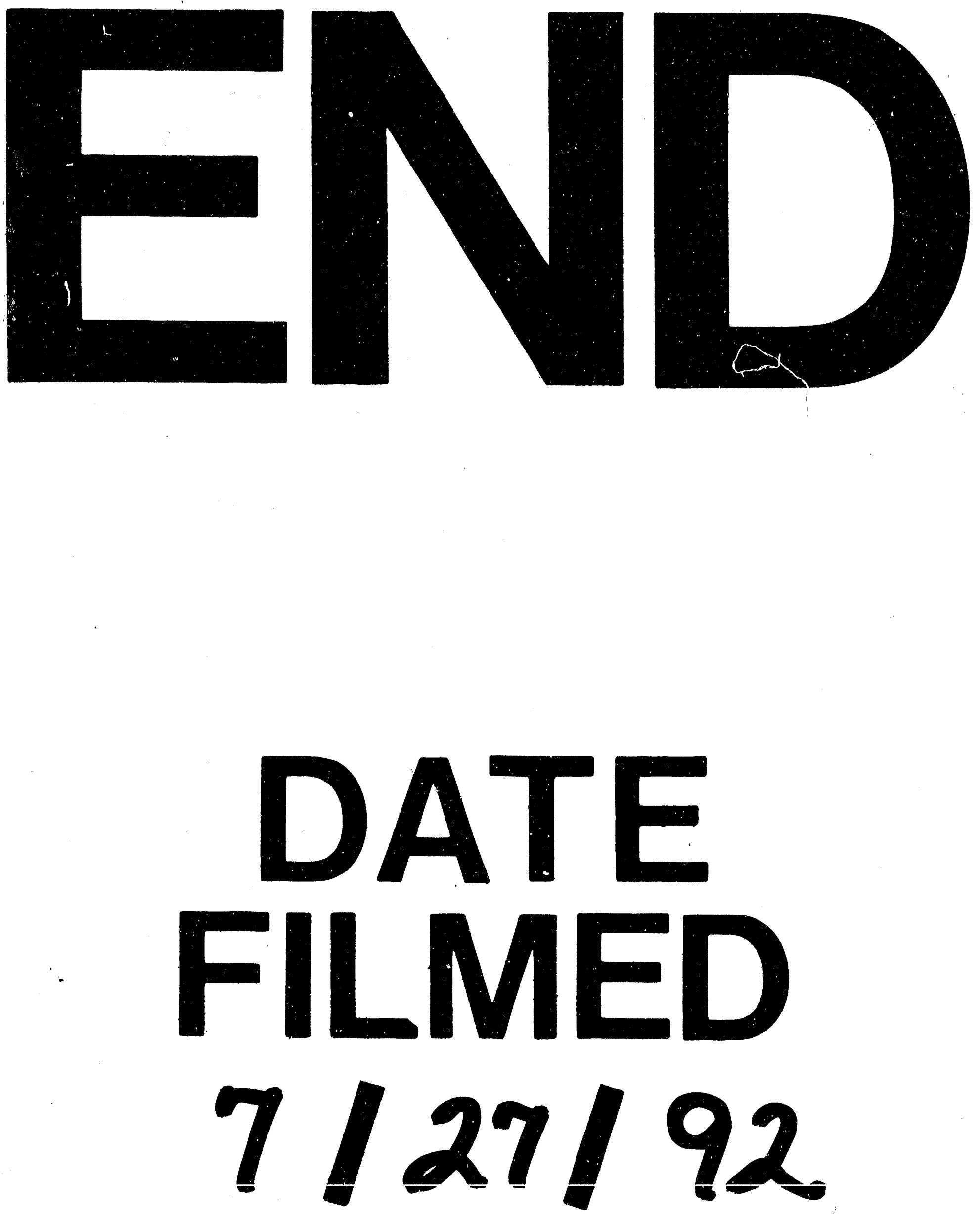

1 
